\title{
A Study of Human and Animal Imagery in the Poems of Ted Hughes
}

\section{Kumar Chandrahas}

Research Scholar

P. G. Department of English

Tilka Manjhi Bhagalpur University

Bhagalpur, Bihar, India

arijit.rise@gmail.com

\begin{abstract}
Ted Hughes (1930-1998) began his career as a poet with the publication of The Hawk in the Rain in 1957. He was labelled as "an animal poet". The cause of disintegration in modern man is his cutting from the elemental nature of his own. Modern man appears to be Yeats's 'falcon' (Yeats, line 2) that goes on decentring himself without cognition and getting absentminded of the life-force, 'the elemental power circuit of the universe'. Science and technology lead to reasoning, and reasoning leads to scepticism, and scepticism creeps into human brain (the egg-head) and causes man to question the validity of spirituality and morality. It is this which has been focussed in this article.

Keywords: Man, Animal, Images, Mind, Nature, Life.

In an essay review of Mark Nicholson's The Environmental Revolution, Ted Hughes states:
\end{abstract}

When something abandons Nature, or is abandoned by Nature, it has lost touch with its creator, is called an evolutionary dead-end. According to this, our civilisation is an evolutionary error. (Winter Pollen, 129) 
He further adds that "The story of the mind exiled from Nature is the story of Western Man." (Winter Pollen, 129) It is because of the denial of inner and outer nature that the Western civilisation receives its spiritual collapse and environmental destruction. The spiritual sterility causes man to break with nature and its power. Hughes perceived this spiritual decline of Western Man, beginning with Reformation and the rise of "a masculine strain of Christianity that denied that body and demoralised nature and its sovereign goddess," (Brandes, 526) along with simultaneous rise of science and technology.

Most of the human characters in Hughes' poems that they are deprived of vitality and energising force of the universe. Such humans frequent nature as hesitant visitors and fear to confront any violent display of energy, and sometimes they feel jealous of the instinctual perfection in animals and natural world. But it was not so in primitive times when primitive men lived in the heart of nature and were in direct contact with animals and natural energies, and nature, men and animals - all were in perfect harmony, such perfection is seen in gymnastic movement of an acrobat while walking on the rope. (Lupercal, Hughes)

The human protagonist in 'The Hawk in the Rain' appears as a foil to the hawk and is prey to the swallowing earth's mouth. On a rainy day he is struggling in the mud of the plough to come out to his ordinary existence. The earth, it seems to him, haunts him like a tenacious grave as his feet sink into the mud. But the hawk with its still eyes effortlessly keeps a watch from a height. The frailty of the man image is subjected to the stout image of the hawk that, in the banging wind and heavy rainfall, hangs still against the main support of violence. But, the human protagonist, in the mortal drama of life, feels utterly exhausted and defeated counting his last moment being grabbed bloodily.

Here the man is presented as a figure devoid of instinctual and elemental force having no correlation with nature and animals, easily frustrated and disappointed, and sharing no features to primitive men. 
In 'The Jaguar' (The Hawk in the Rain), the human protagonist is merely a passive visitor to the cage of the jaguar. Again, man and animal are in close encounter with each other. The jaguar, though in a cage, is fully possessed with vitality and vehemence, and the man, the speaker, stands before its cage utterly mesmerised. He becomes slave to the wilderness of liberty that the jaguar's stride has. The man looks like a pygmy before the caged jaguar, unlike the hawk at the height of liberty.

But, 'Macaw and Little Miss' (The Hawk in the Rain) portrays a small girl that confronts the hidden stirring forces in her unconscious mind. She is such a human figure that is ignorant, youthful and immature, unconscious of the volcanic temperament of the macaw. The macaw remains reluctant to her cajoling, caress, whispers and kisses. But on pricking it bursts into conflagration and hysteria and its shriek shakes the entire house. Thus, we see immaturity and ignorance in a human leading her to some disastrous blunder. That is why in her dream the forces of the underworld and nightmarish images prick her unconscious mind and compels her to realise the hidden powers (of the underworld). But these primitive/images remain latent in her unconscious mind.

The man in 'The Dove-Breeder' (The Hawk in the Rain) shows metamorphic influence on his part. The dove-breeder is a mild-mannered and sentimental individual. He would have been a man of poor instincts and fragile emotions. The images of 'dove and hawk' reflect a conflict between emotionalism and rationalism respectively. Emotionalism develops negative feedback and the dove-breeder "will win no more prizes" unless he exempts himself from the weak side of his character. Life's race must be conquered and he has to let the hawk raid the dove, that is, softness must be changed into stiffness. The dovebreeder admits the truths of survival of the fittest and soon he

... dried his tears

Now he rides the morning mist 
With a big-eyed hawk on his fist. (The Hawk in the Rain, 23)

The dove stands for quietness and gentility and the hawk for vitality and ferocity and denotes the elemental force lying at the core of the universe. Here, the metaphoric-cummetaphoric transformation of the dove-breeder into the hawk-trainer is worth-noticing. It is also an alchemical change in his character, perceptive that Hughes has developed in detail in Cave Birds.

'Parlour-Piece' and 'Secretary' (The Hawk in the Rain) are two such poems which show lack of contact in humans. It is hamartia to their tragic life. The former poem shows how the two lovers who have caged their primal energies in their heart are indifferent to their true instincts.

With love so like fire they dared not

Let it out into strawy small talk;

These two sat speechlessly:

Pale cool tea in tea-cups chaperoned

Stillness, silence, the eyes

Where fire and flood strained. (The Hawk in the Rain, 20)

The imagery of "pale cool tea in tea-cups" conveys dissociation and isolation in humans, in the two lovers. But the latter poem depicts the divided nature of the secretary. To her even a soft, loving touch is as fatal as a dreadful wound. At the first sound of horn she is off in a flurry; ducking, peeping, she hurries forward among men. At last, after finishing her routine works she

Goes to bed early, shuts out with the light

Her thirty years, and lies with buttocks tight,

Hiding her lovely eyes until day break. (The Hawk in the Rain, 21) 
Unlike the immoral, unscrupulous and erotic typist girl in 'The Fire Sermon' of The Waste Land by W. B. Yeats, the secretary here is of split nature, full of scruples, totally detached from her instincts and elemental energies. She suffers from coitophobia and does not venture into testing her sex instinct, which is an inseparable part of human existence.

Conclusion:

This aversion from a normal and active life and fear of elemental energy is not only limited to a few stray individuals but also applies to the generality of the surviving public who continue to live in a very drab and mechanical existence. In 'Public Bar T.V.' Hughes deals with a group of people suffering from the deadening effects of a commercial medium. Instead of encouraging active participation in life and promoting communal interaction, the public bar has now come to denote an area of stagnation and inactivity. The people who visit the place are tired and defeated souls weary of life's "struts and frets" and oppressed by a constant sense of failure:

Man that have been bending all their lives

In the one dim lamp of a pension

To lift their need, relax as in graves

Lifeless but for the eye-gleams of attention

The haze and sip, like a mountain-range in the dew.

These are the Giant Stupids.

They are grimy to the spinal fluid

As if they slept nightly in the earth. (Keegan, 133)

By providing mechanised entertainment through the TV, the bar had only added to their sense of alienation from society, for now they could no longer participate in life's real activity. The TV has become a symbol of mechanisation, and the deadening alienation follows in its wake. Through these poems, Hughes presents the passive, discouraging and negative approaches of 
human to life and its natural energies. The modern man has become a 'hollow man'. He possesses a detached self, deprived of all the vital forces and is 'cabined' to a little room of rationalism. 


\section{Works Cited:}

Brandes, Rand. "Ted Hughes: Crow", A Companion to Twentieth-Century Poetry, edited by Neil Roberts, New Jersey: Blackwell Publishing, 2001, pp. 526.

Eliot, T.S. "The Waste Land." The Faber Book of Modern Verse, edited by Michael Roberts, 4th ed, London: Faber and Faber, 1982.

Hughes, Ted. Collected Poems, London: Faber and Faber, edited by Paul Keegan, pp. 133.

Hughes, Ted. Lupercal, London: Faber and Faber, 1998.

Hughes, Ted. The Hawk in the Rain, London: Faber and Faber, 1968.

Hughes, Ted. Winter Pollen, London: Faber and Faber, 1994, pp. 129.

Yeats, W.B. "The Second Coming." The Faber Book of Modern Verse, edited by Michael Roberts, $4^{\text {th }}$ ed, London: Faber and Faber, 1982, pp. 77. 